\title{
Graphics for Urban Design
}

\section{Second edition}

\section{Bally Meeda}

\author{
Author: \\ Bally Meeda \\ Graphic design by: \\ Seán McGarr \\ Bally Meeda \\ James Lewis \\ Edited by: \\ Michael Doyle \\ Reviewed by: \\ Caroline Brown \\ Eric Holding \\ Contributors: \\ Caroline Brown \\ Paul Dodd \\ Paul Drew \\ Alice Gadney \\ Robert Huxford \\ Seán McGarr \\ Tim Metcalfe \\ Jon Rowland \\ Fabio Titmus
}

Endorsed by:

\section{URBAN DESIGN GROUP}




\section{Published by ICE Publishing}

One Great George Street, Westminster, London SW1P 3AA.

Full details of ICE Publishing representatives and distributors can be found at: www.icebookshop.com/bookshop_contact.asp

A catalogue record for this book is available from the British Library

ISBN 978-0-7277-6171-2

(c) Thomas Telford Limited 2018

ICE Publishing is a division of Thomas Telford Ltd, a wholly-owned subsidiary of the Institution of Civil Engineers (ICE).

All rights, including translation, reserved. Except as permitted by the Copyright, Designs and Patents Act 1988, no part of this publication may be reproduced, stored in a retrieval system or transmitted in any form or by any means, electronic, mechanical, photocopying or otherwise, without the prior written permission of the Publisher, ICE Publishing, One Great George Street, Westminster, London SW1P 3AA.

This book is published on the understanding that the author is solely responsible for the statements made and opinions expressed in it and that its publication does not necessarily imply that such statements and/or opinions are or reflect the views or opinions of the publishers. While every effort has been made to ensure that the statements made and the opinions expressed in this publication provide a safe and accurate guide, no liability or responsibility can be accepted in this respect by the author or publishers.

While every reasonable effort has been undertaken by the author and the publisher to acknowledge copyright on material reproduced, if there has been an oversight please contact the publisher and we will endeavour to correct this upon a reprint.

Cover photo: Proposal for the pedestrianisation of Oxford Street, London, Urban Graphics/Christian Wolmar

Commissioning Editor: James Hobbs

Production Editor: Madhubanti Bhattacharyya

Typeset by: Seán McGarr

Printed and bound in Great Britain by: Bell and Bain, Glasgow

\section{First edition published 2007:}

Bally Meeda, Neil Parkyn and the late David Stuart Walton

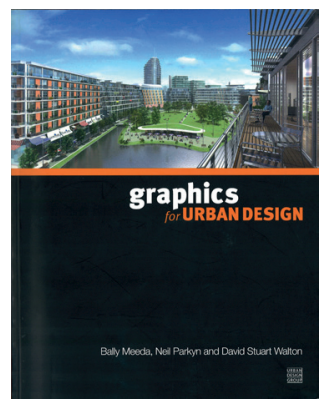




\section{Acknowledgements:}

The author wishes to thank the following organisations for contributing their graphics, illustrations, photographs, and other contributions to make this book possible.

David Lock Associates is an independent town-planning, urban design and masterplanning consultancy based in Milton Keynes. Founded over 30 years ago, they advise landowners, developers, businesses and local authorities. They are responsible for many of the UK's most transformative masterplans and urban design strategies which are changing the way communities and subregions in the UK grow and prosper.

\section{DOYLE}
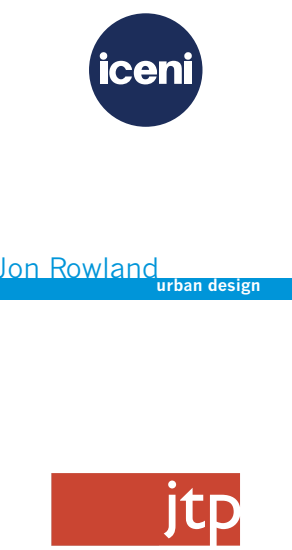

\section{Pollard Thomas Edwards}

Doyle is an independent town planning and urban design practice based in London and Brighton. They help create neighbourhoods, town centres and public places which people value.

Iceni Projects is a multi-skilled team guiding clients through the fast-changing UK planning system. They take a creative approach to planning, urban design, sustainability, engagement, delivery, heritage, transport and EIA management.

Jon Rowland Urban Design is a small practice set up in 1996. The practice carries out a wide range of urban design projects in the UK and abroad. It works with a network of similar practices to promote a cross-professional approach to urban development and regeneration.

JTP is an international placemaking practice of architects and masterplanners with extensive experience of delivering successful projects for both private and public sectors throughout the UK, Europe, China, Russia and the Middle East.

Pollard Thomas Edwards combines design talent, commercial acumen and social commitment to lift everyday places out of the ordinary. Their core services are architecture, masterplanning and urban design, property development and community engagement.

Urban Graphics is a specialist communication and graphic design consultancy that serves the town planning, urban design and built environment sectors. They deliver high-quality print, online and interactive tools that help shape the world we live in.

Wei Yang \& Partners is a practice with an international portfolio of town and country planning, masterplanning, urban design and architectural projects. Their experience ranges from public to private sector work, from city-wide masterplans to individual buildings. 


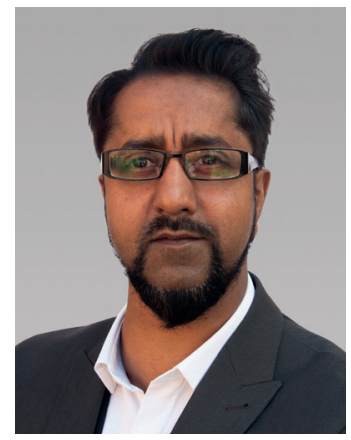

\section{About the author}

Bally Meeda has 30 years of professional experience in the many facets of traditional, digital and interactive design and communication. His knowledge and expertise extend over graphic and exhibition design, cartography, desktop publishing, corporate identity, 3D, interactive mapping, digital design and strategy.

In 1993 he began working as a graphics manager for internationally renowned planning consultancy Llewelyn Davies, who were most famous for the planning of Milton Keynes. The masterplan for Granton Waterfront, Edinburgh, was a project that Bally led on, and it set new heights in computer graphics in the mid-nineties. Prior to setting up his own company, Bally was an associate graphic designer at David Lock Associates, responsible for a team of designers with projects of all scales throughout the UK.

In 2007 Bally wrote the first edition of Graphics for Urban Design, which was endorsed by CABE, the Urban Design Group and other leading urban design practices. This book of in-depth practical guidance was the first of its kind, and was responsible for inspiring a generation of designers and others working in the built environment.

Over the past decade Bally has lectured at Oxford Brookes University, University College London (UCL) and the University of Westminster on graphical communication in urban design, planning and architecture.

He now heads Urban Graphics, one of the UK's leading communication and graphic design companies for the built environment. The company has created some of the world's most innovative and influential campaigns within the fields of planning and urban design. In 2010, Urban Graphics put together a comprehensive communication campaign for Konza Technology City in Kenya. It was key to attracting the buy-in of international investors to fund this major new city that is currently under development. Closer to home, Bally was responsible for the visionary computer-generated image of the pedestrianisation of Oxford Street in 2014. This vision is now being considered as a possible reality.

Outside Urban Graphics, Bally spends time writing and producing music. 


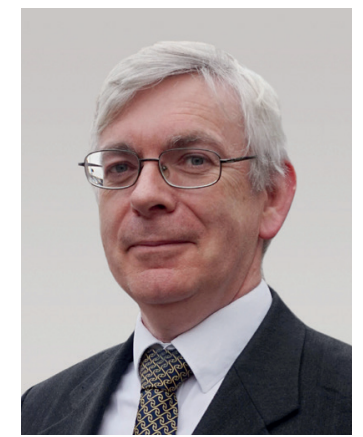

Visual images are a powerful means of communicating ideas. They can explain ideas and proposals clearly and swiftly to people with no design training or understanding of architecture or landscape, and enable local communities to participate fully in discussions about new development.

They can provide clients and politicians with vital and sometimes complex information to help them reach informed decisions. Graphical images provide a common means of communication that can help multi-disciplinary teams, with different professional languages, work towards a common vision. It is unsurprising, therefore, that Graphics for Urban Design is now a specialist subject in its own right.

There are so many graphical communication tools available nowadays that the choice can be overwhelming. This guide, now in its second edition, provides practical help in choosing the best tools for the job; the processes; the techniques; and how to manage them effectively.

Graphics for Urban Design is a guide on how to create better graphics. It does not claim to be a guide to good urban design. However, good graphical communication of good urban design is effective, persuasive and a force for good. Good graphical communication of bad urban design can beguile and mislead, and the damage done to a town or city can be measured in decades and centuries.

The intention of this guide is to help producers of graphical communication to be more aware of the impact of their work, to understand the power that they have to shape the world in which we live, and to use that power responsibly and to the benefit of future generations.

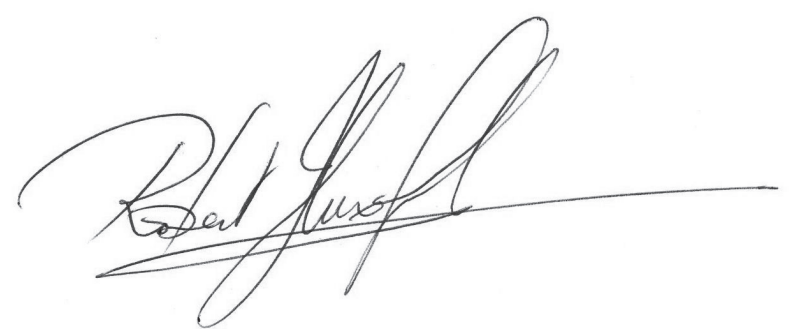

Robert Huxford

Director, Urban Design Group 


\section{CONTENTS}

\section{SECTION A: SETTING THE SCENE}

(1) INTRODUCTION

1.1 The importance of graphics in urban design

(2) THE EVOLUTION OF URBAN GRAPHICS

2.1 The history of urban graphics

(3) THE CHARACTERISTICS OF URBAN DESIGN IMAGES

3.1 Qualities of urban design images

\section{SECTION B: THE PROCESS}

(4) GRAPHICS IN THE URBAN DESIGN PROCESS

4.1 Using graphics in the urban design process 38

4.2 Analysis diagrams $\quad 44$

4.3 Participation and engagement 50

4.4 The urban design rationale $\quad 54$

4.5 Final proposals $\quad 58$

4.6 Supporting final proposals
60 


\section{SECTION C: HOW TO CREATE DRAWINGS}

5) PRODUCING DRAWINGS

$\begin{array}{lll}5.1 & \text { How to create urban design drawings } & 76 \\ 5.2 \text { Case studies } & 88\end{array}$

\section{SECTION D: GOOD PRACTICE}

6) GOOD TECHNICAL PRACTICE

6.1 Good practice methods

6.2 Urban graphics top tips

100

6.3 Using graphics software

120

7 ouTPuTs

7.1 Physical graphical outputs

7.2 Online graphical outputs

137

8 MANAGING PRODUCTION

8.1 Project planning

142

8.2 Useful information

158

Illustration \& photography credits

160 